An Analysis of Disaster Risks and Prevention Methods of Government Commercial Banks in Sri Lanka

By

V.G.C. Thushara

GSIMSCIMGT/3451/2008

Thesis submitted to the University of Sri Jayewardenepura for the award of the Degree of Master of Science in Management 


\section{DECLARATION}

The work described in this thesis was carried out by me under the supervision of Professor Kennedy D Gunawardana and a report on this has not been submitted in whole or in part to any university or any other institution for another Degree/Diploma.

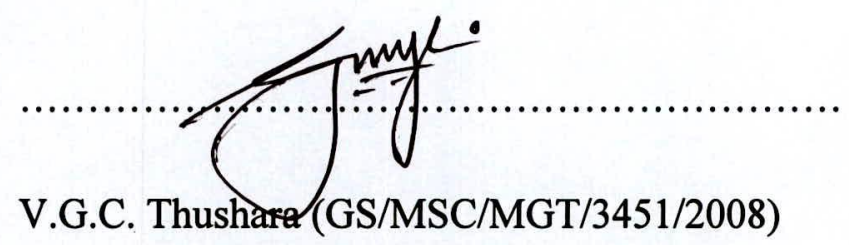




\section{CERTIFICATION}

I certify that the above statement made by the candidate is true and that thesis is suitable for submission to the University for the purpose of evaluation.
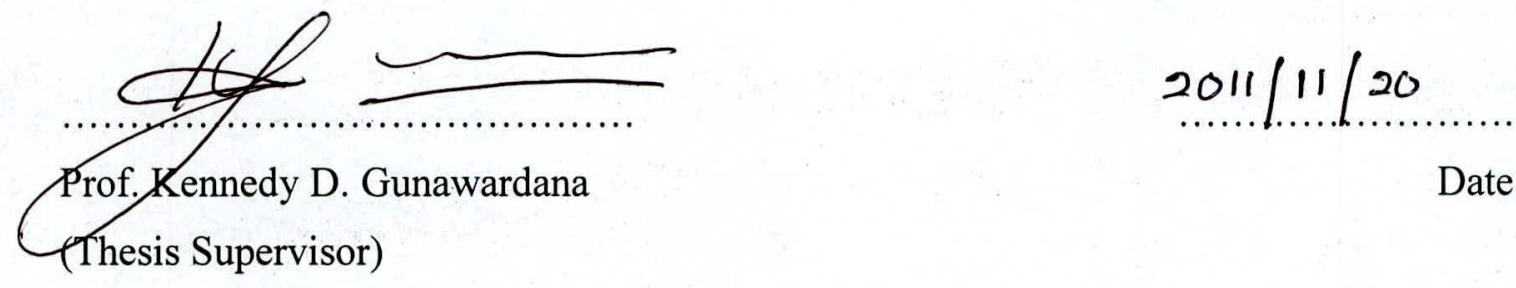

Prof. Dr. Kennedy D. Gunawardana

B.Sc(SJP). MBA(Col), PHD(Abac), CMA(Au)

Prof of Accounting, Department of Accounting

University of Sri Jayewardenepura,

Nugegoda, Sri Lanka. 


\section{Table of contents}

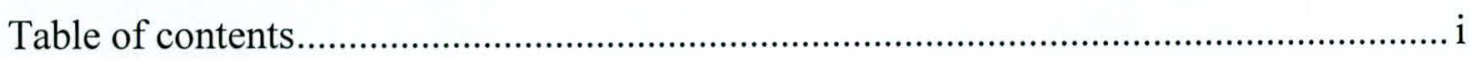

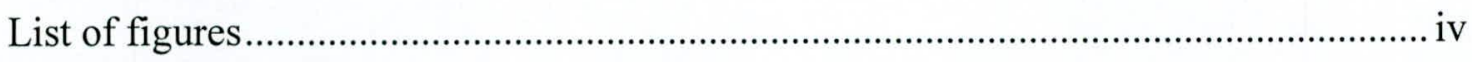

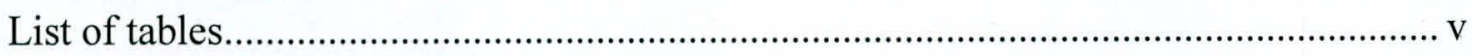

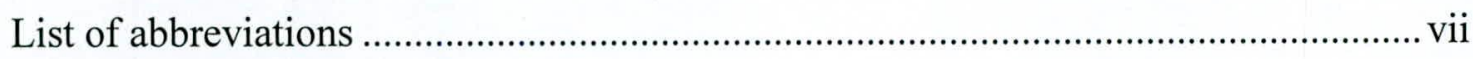

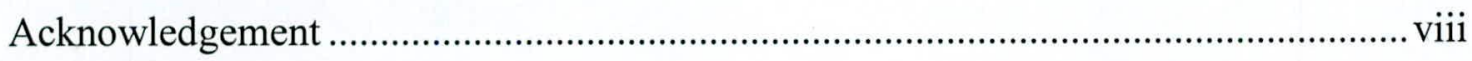

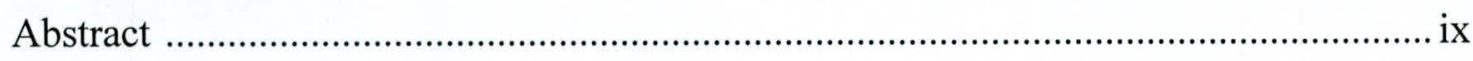

1. CHAPTER 01 INTRODUCTION..................................................................... 1

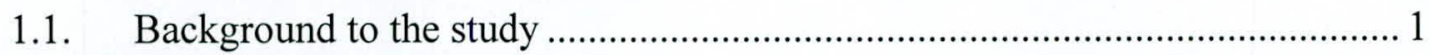

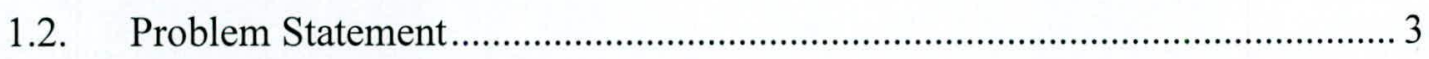

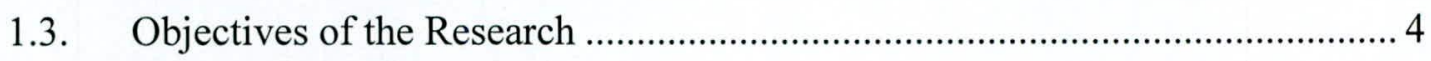

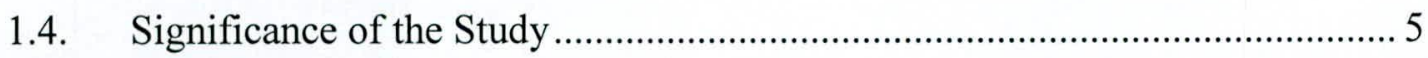

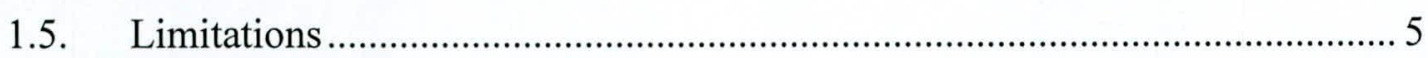

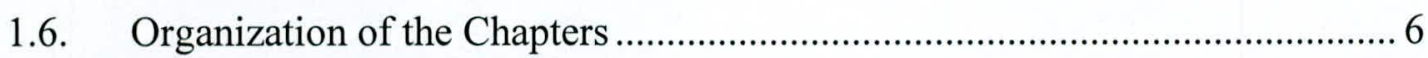

2. CHAPTER 02 LITERATURE REVIEW ...................................................... 9

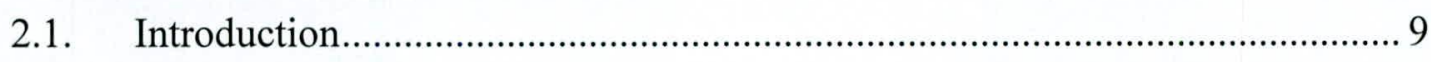

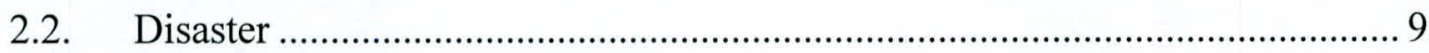

2.2.1. Most common disaster causes............................................................. 10

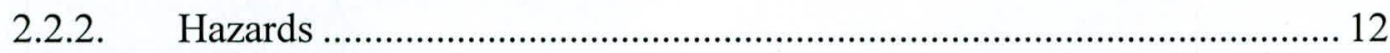

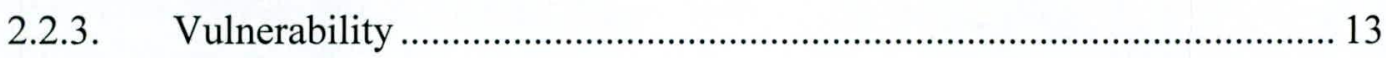

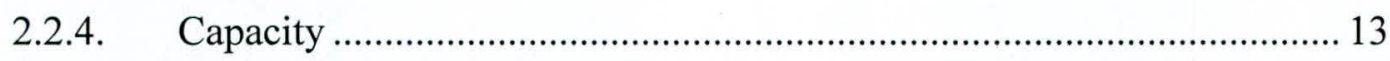

2.2.5. Business impact of Disasters ….......................................................... 14

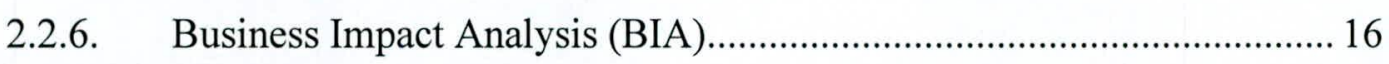

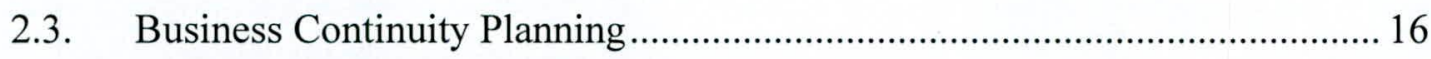

2.3.1. Benefits of Business continuity planning ............................................. 18

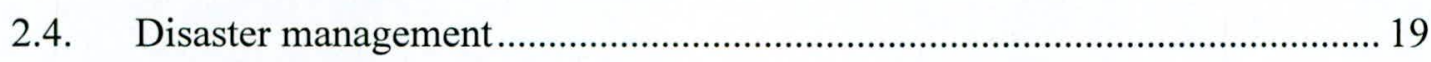

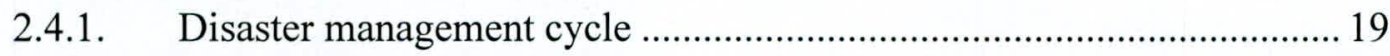

2.4.2. Disaster Recovery Process.............................................................. 21 
2.4.3. Disaster Recovery Plan...................................................................... 22

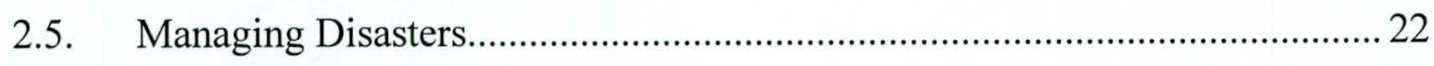

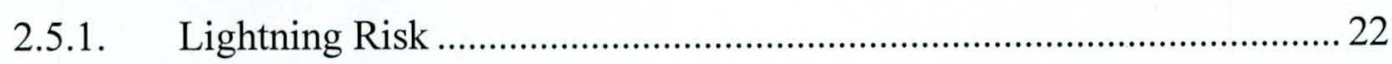

2.5.2. Lightning Protection Systems (LPS) .................................................. 23

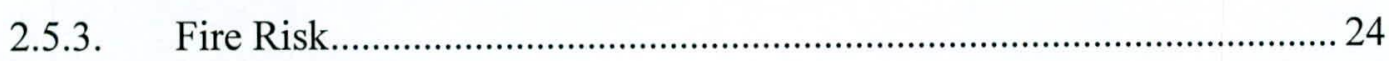

2.5.4. Protecting from Fire ........................................................................ 24

2.5.5. Man-made disasters ........................................................................... 26

2.5.6. Information Systems / Information technology disasters ....................... 26

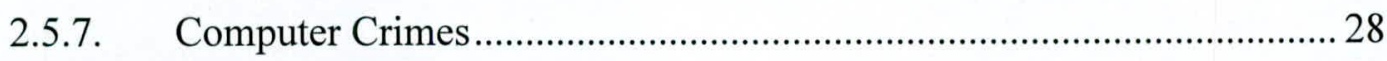

2.6. Disasters happened in or impacted on Sri Lanka........................................ 29

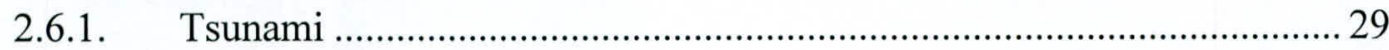

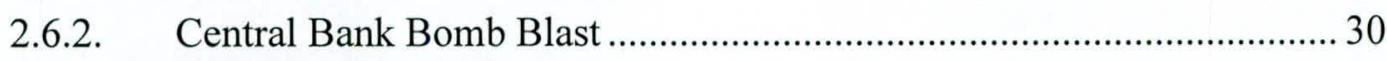

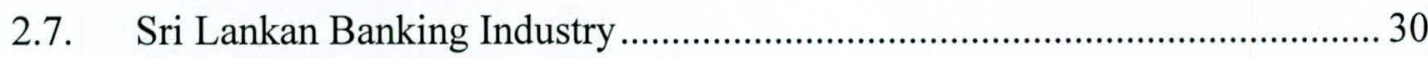

2.7.1. Contribution of the commercial banks to the Nation............................. 31

2.7.2. Bank of Ceylon and People's Bank ....................................................... 32

2.8. Central Bank Guideline Regarding Business Continuity Plan ....................... 33

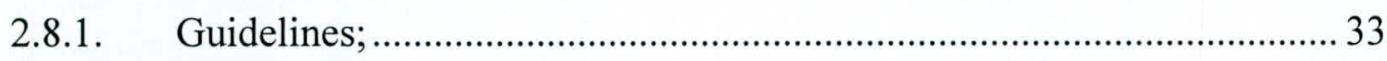

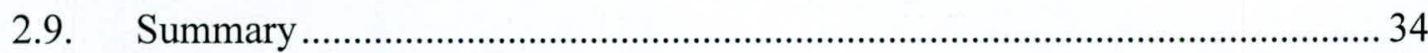

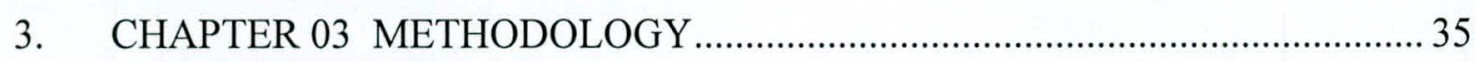

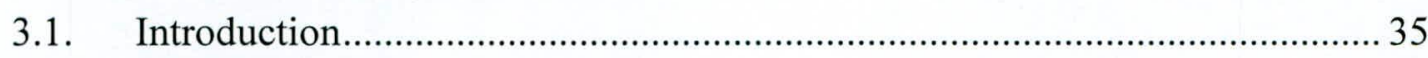

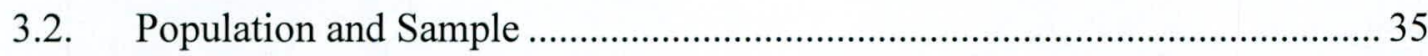

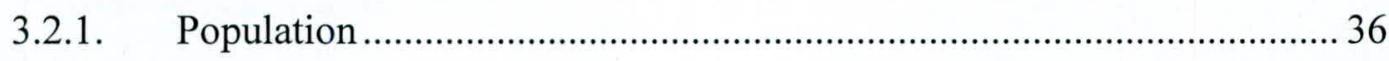

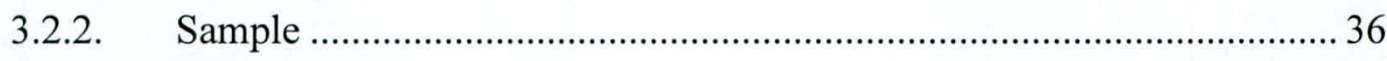

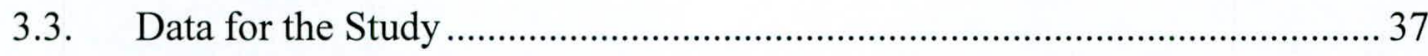

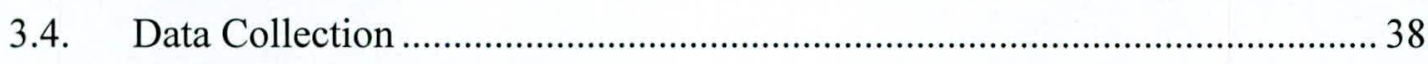

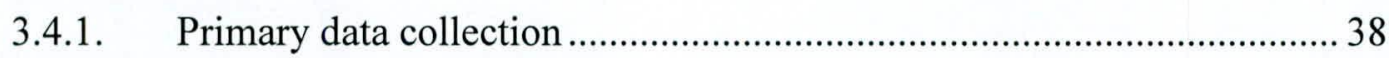

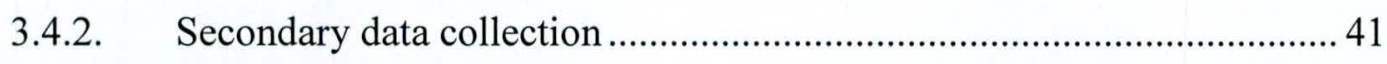

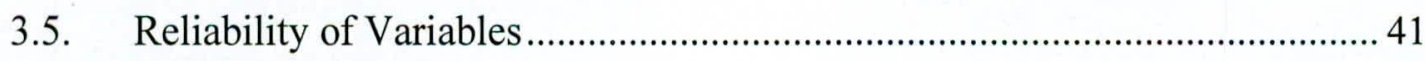

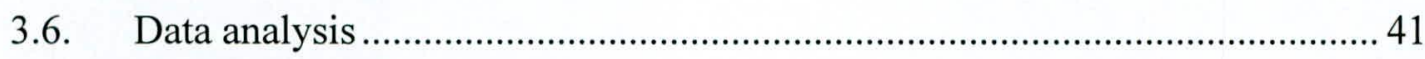

3.6.1. Statistical Techniques ..................................................................... 42

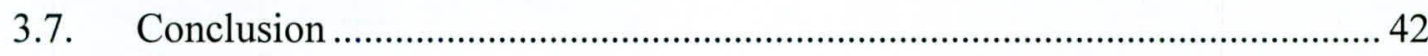


4.1. Introduction...

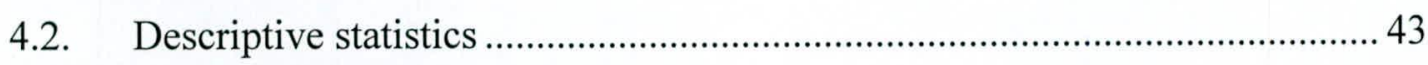

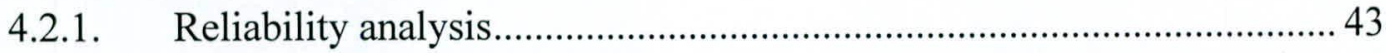

4.2.2. Presentation, analysis and discussion of demographic data .................. 44

4.2.3. Comparison of risks between two banks ............................................. 52

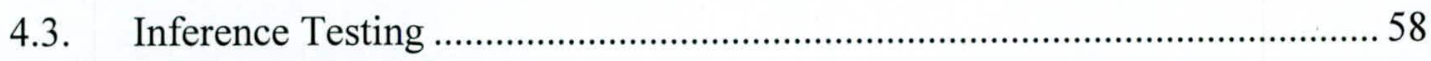

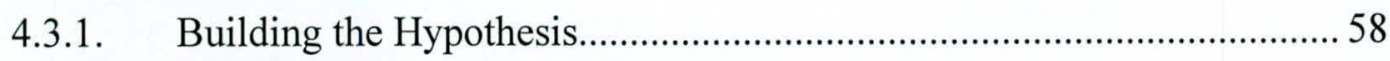

4.3.2. Summary of the result of hypothesis testing........................................67 67

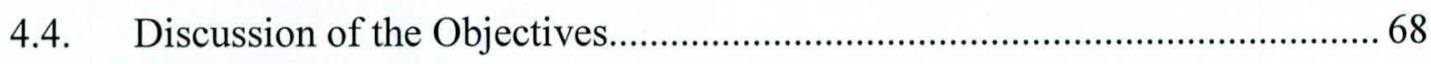

4.4.1. Objective 01 : To measure the existing level of disaster risk and prevention methods in the government commercial banks ................................. 68

4.4.2. Objective 02 : To find out the factors affecting to the disaster risk and prevention methods within the government commercial banks ............................ 69

4.4.3. Objective 03 : To find out the differences of disaster risk and prevention methods among the government commercial banks................................................6 69

4.4.4. Objective 04 : To find out the relationship between characteristics of the government commercial banks and disaster risk and prevention methods............. 70

4.4.5. Findings based on the observations carried out in site visits ................. 71

5. CHAPTER 05 CONCLUSIONS AND RECOMMENDATIONS …................... 73

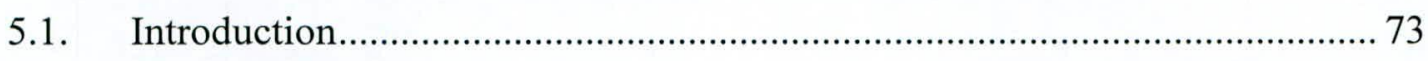

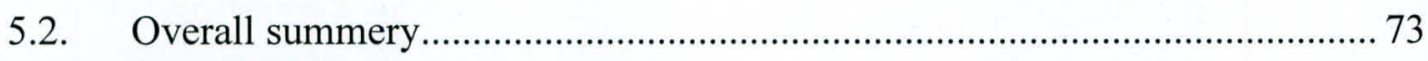

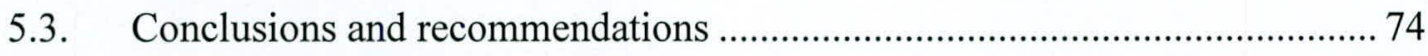

5.3.1. Risks, Challenges and barriers based on analyzed data........................ 74

5.3.2. Risks, challenges and barriers based on observations .......................... 75

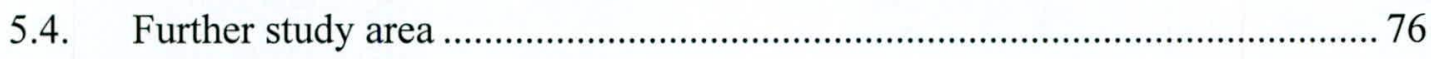

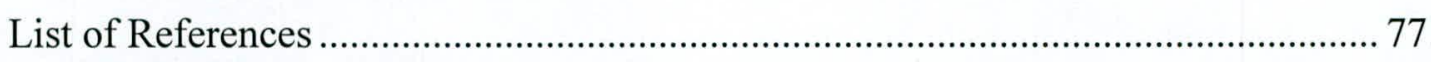

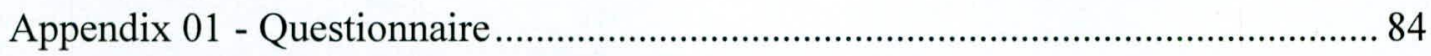

Appendix 02 - Branch network of Bank of Ceylon ................................................. 95

Appendix 03 - Branch network of People's Bank ................................................. 104

Appendix 04 - Central Bank guideline for license commercial banks ..................... 110 


\section{List of Figures}

Figure 2.1: Vulnerability Hazard and Disaster. 14

Figure 2.2 : Disaster Management Cycle.................................................................... 20

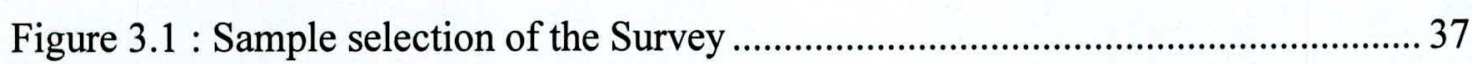

Figure 4.1 : Percentages of Banks ............................................................................. 45

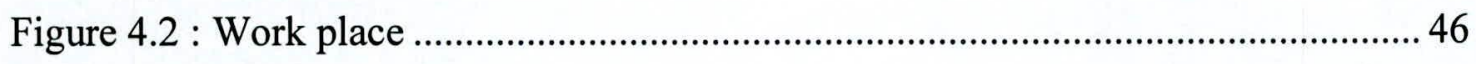

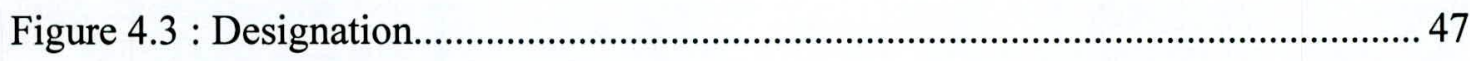

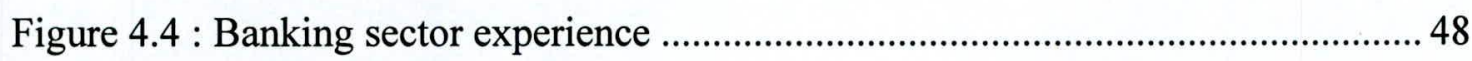

Figure 4.5 : Time period in the current job title.............................................................. 49

Figure 4.6 : Educational Qualification........................................................................ 50

Figure 4.7 : Years of experience in IT field................................................................ 51 


\section{List of Tables}

Table 4.1 : Variable categories and their Cronbach's Alpha values. 44

Table 4.2 : Number of units in the sample (banks) and the percentage 45

Table 4.3 : Work place. 46

Table 4.4 : Designation 47

Table 4.5 : Banking sector experience. 48

Table 4.6 : Experiences in the current job title

Table 4.7 : Educational Qualification of the respondents 50

Table 4.8 : Years of experience in IT field 51

Table 4.9 : Mean values of Bank of Ceylon Natural Disaster Risk 53

Table 4.10 : Mean values of People's Bank Natural Disaster Risk 53

Table 4.11 : Mean values of Bank of Ceylon Manmade Disasters Risk 55

Table 4.12 : Mean values of People's Bank Manmade Disasters Risk 56

Table 4.13 : Mean values of Bank of Ceylon Technical Failure Risk 56

Table 4.14 : Mean values of People's Bank Technical Failure Risk 57

Table 4.15 : T-test on Natural disaster risk of Bank of Ceylon and People's Bank 59

Table 4.16 : T-test on manmade disaster risk of Bank of Ceylon and People's Bank ... 60

Table 4.17 : T-test on Technical failure risk of Bank of Ceylon and People's Bank 62

Table 4.18 : T-test on Natural disaster prevention measures of Bank of Ceylon and People's Bank 63 
Table 4.19: T-test on manmade disaster prevention measures of Bank of Ceylon and People's Bank . 65

Table 4.20 : T-test on Technical failure prevention measures of Bank of Ceylon and People's Bank .66 


\section{List of abbreviations}

\begin{tabular}{|c|c|}
\hline $\mathrm{AC}$ & Air Conditioner \\
\hline ATM & Automated Teller Machine \\
\hline $\mathrm{BCP}$ & Business Continuity Plan \\
\hline BIA & Business Impact Analysis \\
\hline $\mathrm{BOC}$ & Bank of Ceylon \\
\hline CBSL & Central Bank of Sri Lanka \\
\hline CCTV & Closed Circuit Television \\
\hline CEB & Ceylon Electricity Board \\
\hline DBMS & Data Base Management Systems \\
\hline DRP & Disaster Recovery Plan \\
\hline DRT & Disaster Recovery Team \\
\hline EDP & Electronic Data Processing \\
\hline IS & Information Systems \\
\hline ISO & International Standard Organization \\
\hline $\mathrm{ICT}$ & Information and Communication Technology \\
\hline IT & Information Technology \\
\hline LAN & Local Area Network \\
\hline LPS & Lightning Protection Systems \\
\hline $\mathrm{PB}$ & People's Bank \\
\hline RTGS & Real Time Gross Settlement \\
\hline SLT & Sri Lanka Telecom \\
\hline SPSS & Statistical Package for Social Scientist \\
\hline UPS & Uninterrupted Power Supply \\
\hline
\end{tabular}




\section{ACKNOWLEDGEMENT}

This thesis would not have been possible if I did not receive the extended support given by my supervisor. I am grateful to my supervisor, Professor Kennedy D Gunawardana, Senior lecturer, Department of Accounting, University of Sri Jayewardenepura for his invaluable guidance and encouragement.

Special thanks go to Mr. Jayashantha and Mr. Emil De Silva of Bank of Ceylon and Mr. K.H.L. Chandrasiri (DGM-HRM) and Mr. Lakshman (Branch Manager-Head office) of Peoples Bank for their invaluable support in tackling disaster recovery related issues.

I should thank to Dr. P.D. Nimal, Coordinator, M.Sc. in Management program for the support given to me in conducting this study. Further I extend my special thanks to Mr. P.D.K. Amitha Kumara (Coordinator-ITRC), Mr. K.L.S.L. Abeywickrama and to Mr. Chesmi Kumbalathara of Information Technology Resource Centre and other colleagues for being with me generously stretching out their helping hands.

I appreciate the support given to me by all the Managers and other executive staff of Bank of Ceylon Head office, Data centre and branches and People's Bank head office, Data centre and branches, who filled the questionnaires carefully by spending their valuable time.

I must never forget the great assistance and encouragement given to me by my parents and my wife. I should express my love to my little daughter "Tharuli" since I did not have much time to cuddle you. Last but not least I would like to thank everybody who helped me to achieve this goal.

V.G.C. Thushara (GS/MSC/MGT/3451/2008) 


\title{
An Analysis of Disaster Risks and Prevention Methods of Government Commercial Banks in Sri Lanka
}

\author{
By: V.G.C. Thushara
}

\begin{abstract}
Past incidents show that the chance for disasters irrespective of the cause is in an increasing trend. Natural, Manmade and Technically generated disasters occurred in a higher frequency than before. Some of these disasters can be avoided if correct prevention measures were practiced and some disaster situations such as Tsunami cannot be controlled.
\end{abstract}

However a properly designed disaster recovery plan helps to recover in a greater success in an event of a disaster. It will guide to establish the essential functions within a fairly considerable time period.

The world is moving towards a knowledge economy where the key strategic resource becomes the knowledge or "Information". At present, organizations consider data and information as the most valuable asset or strategic weapon which determines the survival and the competitive position of an organization. Information is treated as important as with or higher than labor and capital. Thus, most organizations now are information based and utilize ICT in a greater extent for their business purposes. Same time, the consumers also consider that the time is more precious than before and expect always on, quick services from the business organizations. 
Thus, the need of ensuring the business continuity cannot be undermined. To the far extent possible, the chance for the discontinuities should be avoided and effective strategies should be pre set to practice to recover from the discontinuities if happened.

Banking industry is an industry which has a high utilization of information and information communication technologies for their businesses. In the absence of the information and ICT they cannot operate. Thus with in this study analyses the government commercial banks of Sri Lanka - Bank of Ceylon and People's Bank and the disaster recovery plans of them in order to assess the risks for disaster situations and to evaluate the existing disaster recovery plans in terms of their appropriateness, practice and operation. A cross comparison also made among the banks to identify the differences among the risk and prevention / recovery measures.

Research reveals that the both banks possess the same or similar levels of risks among the risk categories except the possibilities for natural fire related disaster risks and possibilities for Electricity and Power related risks. No significant differences were identified between the two banks among the other risk categories such as manmade disaster risk and technical failure risk. It was identified that People's Bank virus risk and software related risk is higher than those risks of Bank of Ceylon. The measures taken to prevent the chance for the disasters as well as to recover from disasters if happened are almost same between the banks. One reason for this situation is the common guidelines issued by Central Bank of Sri Lanka for the commercial banks on disaster prevention and recovery. Thus, preventing and recovering from natural fire disasters and avoiding electricity generating fire risk were still shown as the challenges for the both banks. 


\section{CHAPTER 01}

\section{INTRODUCTION}

\subsection{Background to the study}

Several decades ago, people used to consider the physical resources such as coal and minerals as the most valuable assets to human beings. However, later, it was identified at several organizations that human resources are more powerful and important than the physical resources, especially in the field of business. With the advancement of Science and Technology in the modern world, in the $20^{\text {th }}$ century, the contribution of both physical and human resources were underestimated to a certain extent, in the commercial world: people began to realize that an information-rich organization is significantly efficient in the field of business: an organization with much information can gain much competitive advantage, in any business.

Commercial banks play a major role in the field of business in Sri Lanka. Sri Lanka is fairly rich with private banks such as Sampath Bank, Hatton National Bank, Saylan Bank, Commercial Bank and state-run banks such as People's Bank and Bank of Ceylon. However, since the majority of Sri Lankans seem to rely on state run banks and since they are situated in almost all the areas in the country, the service rendered by the state-run banks is quite significant in the commercial world, in monetary transactions.

In the past, the banks processed their data through the manual data processing systems. Manual data processing was done with pen and paper with traditional data processing method's its tough and complicating as it consumes more pages and filling it makes the 
data processing work more tedious and tiresome. Many faults/disadvantages could be seen in this manual data processing method. Among them the low speed, low accuracy, storage problems, security issues were there. But all these addressed with the Electronic Data Processing. Electronic Data Processing (EDP) can refer to the use of automated methods to process commercial data. Typically, this uses relatively simple, repetitive activities to process large volumes of similar information.

Thus, it is imperative for these banks to maintain and manipulate the data of their customers in a regular, systematic way. To address this need, the banks have taken action to maintain a data-base system at their organizations: it is reported that the database management system (DBMS) has been beneficial for the organizations to run their business smoothly and efficiently. For instance, due to the data-base system, any customer has the access to his/her financial transactions in any part of the world. Thus, the data-base system available in the commercial banks has been very important for the customers as well to the authorities of the banks to run their business efficiently.

However, what is equally important is to maintain ways and means to protect this data and information because data is easily subject to destruction. People have typically associated disasters with catastrophic events such as fires, hurricanes, and tornadoes. Accordingly, data and information are destroyed due to many reasons. As Wrobel (1997) points out there are three main phenomena that can cause data destruction. They are;

- Natural causes

- Human errors

- Technical Failures 